九州大学学術情報リポジトリ

Kyushu University Institutional Repository

\title{
Effects of Temperature and Host on the Immature Development of the Parasitoid Neochrysocharis okazaki i (Hymenoptera: Eulophidae)
}

Tran, Dang Hoa

Department of Plant Protection, Faculty of Agronomy, Hue University of Agriculture and Forestry

Le, Khac Phuc

Department of Plant Protection, Faculty of Agronomy, Hue University of Agriculture and Forestry

Ueno, Takatoshi

Laboratory of Insect Natural Enemies, Division of Biological Control, Department of Applied Genetics and Pest Management, Faculty of Agriculture, Kyushu University

Takagi, Masami

Laboratory of Insect Natural Enemies, Division of Biological Control, Department of Applied Genetics and Pest Management, Faculty of Agriculture, Kyushu University

https://doi.org/10.5109/22060

出版情報: 九州大学大学院農学研究院紀要. 57 (1)，pp.133-137，2012-02. Faculty of Agriculture， Kyushu University

バージョン :

権利関係 : 


\title{
Effects of Temperature and Host on the Immature Development of the Parasitoid Neochrysocharis okazakii (Hymenoptera: Eulophidae)
}

\author{
Dang Hoa TRAN ${ }^{1}$, Khac Phuc LE ${ }^{1}$, Takatoshi UENO² \\ and Masami TAKAGI ${ }^{2 *}$
}

\author{
${ }^{1}$ Department of Plant Protection, Faculty of Agronomy, Hue University of Agriculture and Forestry, Hue, Vietnam \\ ${ }^{2}$ Laboratory of Insect Natural Enemies, Division of Biological Control, Department of \\ Applied Genetics and Pest Management, Faculty of Agriculture, \\ Kyushu University, Fukuoka 812-8581, Japan \\ (Received October 31, 2011 and accepted November 9, 2011)
}

\begin{abstract}
The development of Neochrysocharis okazakii, an eulophid parasitoid attacking pest Liriomyza leafminers, was studied under laboratory conditions at seven constant temperatures $\left(15^{\circ}, 17.5^{\circ}, 20^{\circ}, 22.5^{\circ}, 25^{\circ}\right.$, $27.5^{\circ}$ and $30^{\circ} \mathrm{C}$ ) on the hosts L. chinensis and L. trifolii. Neochrysocharis okazakii completed development on both host species at all temperatures examined. The total development time from egg to adult emergence was similar on the two host species at $25-30^{\circ} \mathrm{C}$. Male parasitoids developed faster than females did. The developmental time was inversely proportional to temperature, and decreased from 41 to 9 days for temperatures from $15^{\circ}$ to $30^{\circ} \mathrm{C}$, with pupae requiring shorter time for development than the earlier stages. The lower developmental temperature thresholds and degree-days were estimated from linear regression equations. For egg to adult emergence, male $N$. okazakii required 166.7 degree-days (DD) above a lower developmental threshold of $11.5^{\circ} \mathrm{C}$ on $L$. chinensis and $166.7 \mathrm{DD}$ above $11.6^{\circ} \mathrm{C}$ on $L$. trifolii; females required $172.4 \mathrm{DD}$ above $11.3^{\circ} \mathrm{C}$ on $\mathrm{L}$. chinensis and $178.6 \mathrm{DD}$ above $11.3^{\circ} \mathrm{C}$ on $\mathrm{L}$. trifolii. Although the two host species were equally suitable as host for $N$. okazakii, our findings suggested that $L$. trifolii is an ideal host for $N$. okazakii mass-rearing.
\end{abstract}

Key words: biological control, IPM, leafminer, onionpests

\section{INTRODUCTION}

Agromyzid leafminers are known to have many natural enemies, particularly insect parasitoids, in both their native and invaded ranges. Over 40 species of parasitoids have been recorded worldwide from Liriomyza spp. (Waterhouse and Norris, 1987). The communities of these parasitoids have been recognized for their potential contribution to the integrated pest management (IPM) of leafminers in both glasshouses and open fields (Waterhouse and Norris, 1987; Minkenberg, 1990).

Neochrysocharis okazakii Kamijo (Hymenoptera: Eulophidae) is well known as a parasitoid of Liriomyza leafminers, widely common and dominant in warm regions of many Asian countries including China, Japan and Vietnam (Murphy and LaSalle, 1999; Tran et al., 2006). This endoparasitoid is capable of developing on several Liriomyza leafminer species, including L. trifolii (Burgess), L. sativae Blanchard, L. brassicae (Riley) and L. chinensis (Kato) (Saito et al., 1996; Arakaki and Kinjo, 1998; Konishi, 2004; Bjorksten et al., 2005; Tran et al., 2006). This wasp species is also predominant among the parasitoids attacking $L$. chinensis in onion crops, and is likely to be useful for the leafminer control in Vietnam (Tran et al., 2006).

\footnotetext{
1 Department of Plant Protection, Faculty of Agronomy, Hue University of Agriculture and Forestry, Hue, Vietnam

2 Laboratory of Insect Natural Enemies, Division of Biological Control, Department of Applied Genetics and Pest Management, Faculty of Agriculture, Kyushu University, Fukuoka 812-8581, Japan

* Corresponding author (E-mail: mtakagi@grt.kyushu-u.ac.jp)
}

Neochrysocharis okazakii can complete its development on both $L$. chinensis and L. trifolii, with rapid development, giving minimum life cycles of 11-12 days at $25^{\circ} \mathrm{C}$ (Tran and Takagi 2006; Tran et al., 2007). Like other insects, the rate of development of the parsitoid is temperature dependent. The knowledge of thermal constants and lower developmental thresholds provides essential information to determine the development rate of a particular species of arthropod (Jarošík et al., 2002). Developmental rates and threshold temperatures are frequently used to create predictive models of insect development (Lactin et al., 1995). The objectives of our study were to determine the effect of selected constant temperatures and host species $L$. chinensis and L. trifolii on the development rate of immature stages of $N$. okazakii, and to estimate lower developmental thresholds and thermal constant (degree-day) for each stage.

\section{MATERIALS AND METHODS}

\section{Insect rearing}

Colonies of the two leafminers, $L$. chinensis and $L$. trifolii, were maintained separately in MIR-253 Sanyo incubator chambers at $25 \pm 0.5^{\circ} \mathrm{C}, 60-70 \%$ relative humidity and a photoperiod of 16:8 hours light:dark. Liriomyza trifolii had been reared on kidney bean, Phaseolus vulgaris L. (Tran et al., 2004), and L. chinensis was maintained on Welsh onion, Allium fistulosum L. (Tran and Takagi, 2005).

The colony of N. okazakii originated from Hue City, Vietnam. This parasitoid was reared on larvae of $L$. chinensis in the MIR-253 Sanyo incubator chambers at 
$25 \pm 0.5^{\circ} \mathrm{C}, 60-70 \%$ relative humidity and $16: 8 \mathrm{~h}$ light:dark photoperiod at the Laboratory of Entomology, Faculty of Agronomy, Hue University of Agriculture and Forestry, Vietnam in the same manner as described by Tran et al. (2007). Each leaf of the infested onion plants (30-40 cm height, 2-3 leaves per plant) had 20-40 second-and third-instar L. chinensis. For parasitization, four hostinfested potted plants were placed in a plastic cage $(45 \times 30 \times 32 \mathrm{~cm})$ covered with a fine nylon mesh. A piece of tissue paper $(2 \times 2 \mathrm{~cm})$ saturated with a honey solution was placed in the cage to give food for the parasitoids. About 100-200 parasitoids were introduced into the cage. After an exposure for $24 \mathrm{~h}$, these plants were transferred into a vented plastic container $(60 \times 50 \times 40 \mathrm{~cm})$ until pupation of the parasitoids (approximately 6 days after parasitization). The onion leaves with parasitoid pupae were removed from the plant stems and transferred into a polyethylene terephthalate (PET) bottle (1.5 litres). Emergence of parasitoids was checked daily. The parasitoids collected from the bottle were placed in grass vials $(28 \times 60 \mathrm{~mm}$ diameter) and provided with honey immediately after emergence.

\section{Immature development}

The effects of seven constant temperatures $\left(15^{\circ}\right.$, $17.5^{\circ}, 20^{\circ}, 22.5^{\circ}, 25^{\circ}, 27.5^{\circ}$ and $30^{\circ} \mathrm{C}$ ) on the development of $N$. okazakii reared on L. chinensis and L. trifolii were investigated. Experiments were conducted in parallel. Four potted onion plants at 2-3 leaf stage, 30-40 cm high or four potted kidney bean plants with well-developed first post-cotyledon leaves were placed in a plastic cage $(45 \times 30 \times 25 \mathrm{~cm})$ covered with a fine nylon mesh. Fifty mixed sex $L$. chinensis or L. trifolii adults were released in the cage for $2-4 \mathrm{~h}$ to allow oviposition. Then, the potted plants were removed from the cage and held in environmental chambers at a constant temperature of $25^{\circ} \mathrm{C}$ and a photoperiod of 16:8 h light:dark until all leafminer larvae reached the final instar.

Either host plant infested with final-instar leafminers was placed in a plastic cage $(45 \times 30 \times 32 \mathrm{~cm})$ covered with a fine nylon mesh and then mixed sex 2-day-old $N$. okazakii adults were introduced into the cage for parasitism. Female parasitoids were allowed to attack and parasitize leafminer larvae for $6 \mathrm{~h}$. After the parasitization period, the plants were removed. The leaves of onion plants were then dissected under a microscope to check for paralyzed larvae. The paralyzed larvae were removed and placed into Petri dishes (6 cm diameter). A piece of cotton wool saturated with distilled water was laid on each dish, and then a piece of filter paper $(5.5 \mathrm{~cm}$ diameter) was placed on the cotton wool. The paralysed larvae were placed on the paper and then covered with another piece of the filter paper. The leaves of kidney bean plants were cut off and then placed in Petri dishes (9 $\mathrm{cm}$ diameter) lined with a piece of water-saturated cotton wool and filter paper. The dishes with paralyzed larvae were maintained in each of eight environmental chambers set at $15^{\circ}, 17.5^{\circ}, 20^{\circ}, 22.5^{\circ}, 25^{\circ}, 27.5^{\circ}$ and $30^{\circ} \mathrm{C}$, and a $16: 8 \mathrm{~h}$ light:dark photoperiod until pupation of par- asitoids. Parasitoid pupae were collected once per day in the afternoon. The development time of combined egg-larva stages was defined as the time from oviposition until pupa collection. The pupae were individually placed in Petri dishes ( $6 \mathrm{~cm}$ diameter) lined with filter paper. These dishes were placed in the same experimental conditions and supplied daily with some drops of water for maintaining appropriate humidity in the Petri dishes. The day of adult parasitoid emergence and the sex of parasitoids were recorded daily to determine mean development time.

\section{Statistical analysis}

The effect of temperature on development time of $N$. okazakii on L. chinensis and L. trifolii was analyzed with one way analysis of variance (ANOVA). The means were separated by Tukey's HSD test. The combined effects of temperature and host species on development time were tested using two-way ANOVA (SAS Institute, 1998).

The effect of temperature on the developmental rate of various stages (i.e., egg-larva, pupa and total development) was examined by linear regressions using the model: $\mathrm{Y}=b \mathrm{X}+a$ where $\mathrm{Y}$ is the developmental rate (1/ [developmental time]), $\mathrm{X}$ is temperature, and $a$ and $b$ are the regression parameters obtained from the regression. The lower developmental thresholds (To) and the degree-day (DD) requirement were estimated using the parameters: To $=-a / b ; D D=1 / b$ (Campbell et al., 1974).

\section{RESULTS}

Neochrysocharis okazakii completed development on both host species at all temperatures examined. Development time for $N$. okazakii on the two hosts at different temperatures is summarized in Table 1. The total development time was similar on both host species at $25-30^{\circ} \mathrm{C}$, whereas parasitoid development was significantly slower on $L$. trifolii at $17.5-20^{\circ} \mathrm{C}(P<0.0001)$ and $22.5^{\circ} \mathrm{C}(P<0.05)$, and faster at $15^{\circ} \mathrm{C}(P<0.0001)$. Male parasitoids developed faster than females at all tested temperatures.

The development time of each parasitoid stage was inversely related to temperature (Table 1). On L. chinensis, the duration of egg-larva, pupa and total development of females, and pupal stage of males decreased significantly as the temperature increased $(P<0.0001)$, whereas egg-larva development time of males decreased significantly when temperature was increased up $25^{\circ} \mathrm{C}$ $(P<0.0001)$. There was no significant difference between total development duration of males at $27.5^{\circ}$ and $30^{\circ} \mathrm{C}$ $(P>0.05)$. On L. trifolii, the durations of egg-larva and total development of males, and pupa and total development of females decreased significantly as the temperature increased $(P<0.0001)$. There was no significant difference in pupal development duration of males between $25^{\circ}$ and $27.5^{\circ} \mathrm{C}(P>0.05)$, and egg-larva development duration of females between $25^{\circ}$ and $27.5^{\circ} \mathrm{C}(P>0.05)$.

At $15^{\circ} \mathrm{C}, N$. okazakii took about 40 and 41 days to complete its development on $L$. trifolii and L. chinen- 
Table 1. Developmental times (days) of $N$. okazakii reared on L. chinensis and L. trifolii at different constant temperatures

\begin{tabular}{|c|c|c|c|c|c|c|c|c|}
\hline \multirow{2}{*}{ Temp. } & \multirow{2}{*}{ Stage } & \multicolumn{2}{|c|}{ L. chinensis } & \multicolumn{2}{|c|}{ L. trifolii } & \multicolumn{3}{|c|}{ Sources of variation $(P)$} \\
\hline & & Male & Female & Male & Female & Sex & Species & Sex $\times$ species \\
\hline \multirow{4}{*}{$15^{\circ} \mathrm{C}$} & Egg + larva & $19.6 \pm 0.36 \mathrm{a}$ & $20.7 \pm 0.24 \mathrm{a}$ & $19.5 \pm 0.19 \mathrm{a}$ & $20.0 \pm 0.18 \mathrm{a}$ & $<0.05$ & NS & NS \\
\hline & Pupa & $20.4 \pm 0.25 \mathrm{a}$ & $21.3 \pm 0.23 \mathrm{a}$ & $19.9 \pm 0.13 \mathrm{a}$ & $20.5 \pm 0.13 \mathrm{a}$ & NS & $<0.0001$ & NS \\
\hline & Total & $41.0 \pm 0.35 \mathrm{a}$ & $41.9 \pm 0.19 a$ & $39.5 \pm 0.22 \mathrm{a}$ & $40.5 \pm 0.22 \mathrm{a}$ & $<0.001$ & $<0.0001$ & NS \\
\hline & $\mathrm{N}$ & 24 & 26 & 48 & 61 & & & \\
\hline \multirow{4}{*}{$17.5^{\circ} \mathrm{C}$} & Egg + larva & $14.0 \pm 0.24 \mathrm{~b}$ & $14.3 \pm 0.17 \mathrm{~b}$ & $15 \pm 0.26 \mathrm{~b}$ & $15.6 \pm 0.25 b$ & NS & $<0.0001$ & NS \\
\hline & Pupa & $14.5 \pm 0.17 \mathrm{~b}$ & $15.0 \pm 0.17 \mathrm{~b}$ & $14.5 \pm 0.19 b$ & $14.9 \pm 0.19 b$ & $<0.05$ & NS & NS \\
\hline & Total & $28.6 \pm 0.33 b$ & $29.3 \pm 0.23 b$ & $29.6 \pm 0.22 b$ & $30.6 \pm 0.29 b$ & $<0.05$ & $<0.001$ & NS \\
\hline & $\mathrm{N}$ & 28 & 46 & 36 & 45 & & & \\
\hline \multirow{4}{*}{$20^{\circ} \mathrm{C}$} & Egg + larva & $10.2 \pm 0.18 c$ & $10.2 \pm 0.16 c$ & $10.7 \pm 0.26 c$ & $11.4 \pm 0.32 \mathrm{c}$ & NS & $<0.001$ & NS \\
\hline & Pupa & $10.1 \pm 0.12 \mathrm{c}$ & $10.2 \pm 0.08 c$ & $10.3 \pm 0.19 c$ & $10.5 \pm 0.14 c$ & NS & NS & NS \\
\hline & Total & $20.3 \pm 0.17 \mathrm{c}$ & $20.4 \pm 0.11 \mathrm{c}$ & $21 \pm 0.26 c$ & $21.9 \pm 0.3 \mathrm{c}$ & $<0.05$ & $<0.0001$ & NS \\
\hline & $\mathrm{N}$ & 22 & 29 & 29 & 35 & & & \\
\hline \multirow{4}{*}{$22.5^{\circ} \mathrm{C}$} & Egg + larva & $7.7 \pm 0.15 \mathrm{~d}$ & $8.0 \pm 0.08 d$ & $8.2 \pm 0.14 \mathrm{~d}$ & $8.6 \pm 0.14 d$ & $<0.05$ & $<0.0001$ & NS \\
\hline & Pupa & $7.7 \pm 0.08 \mathrm{~d}$ & $7.6 \pm 0.06 \mathrm{~d}$ & $7.4 \pm 0.08 \mathrm{~d}$ & $7.6 \pm 0.11 \mathrm{~d}$ & NS & NS & NS \\
\hline & Total & $15.4 \pm 0.12 \mathrm{~d}$ & $15.6 \pm 0.09 d$ & $15.7 \pm 0.14 \mathrm{~d}$ & $16.1 \pm 0.13 \mathrm{~d}$ & $<0.05$ & $<0.05$ & NS \\
\hline & $\mathrm{N}$ & 35 & 83 & 55 & 38 & & & \\
\hline \multirow{4}{*}{$25^{\circ} \mathrm{C}$} & Egg + larva & $6.1 \pm 0.07 \mathrm{e}$ & $6.3 \pm 0.08 \mathrm{e}$ & $6.4 \pm 0.12 \mathrm{e}$ & $6.3 \pm 0.1 \mathrm{e}$ & NS & NS & NS \\
\hline & Pupa & $5.9 \pm 0.05 \mathrm{e}$ & $5.9 \pm 0.08 \mathrm{e}$ & $5.5 \pm 0.11 \mathrm{e}$ & $5.9 \pm 0.13 \mathrm{e}$ & NS & $<0.05$ & NS \\
\hline & Total & $12.1 \pm 0.5 \mathrm{e}$ & $12.2 \pm 0.09 \mathrm{e}$ & $11.7 \pm 0.16 \mathrm{e}$ & $12.2 \pm 0.16 \mathrm{e}$ & $<0.05$ & NS & NS \\
\hline & $\mathrm{N}$ & 19 & 42 & 33 & 55 & & & \\
\hline \multirow{4}{*}{$27.5^{\circ} \mathrm{C}$} & Egg + larva & $5.2 \pm 0.09 \mathrm{e}$ & $5.6 \pm 0.13 \mathrm{f}$ & $5.4 \pm 0.13 \mathrm{f}$ & $5.7 \pm 0.15 \mathrm{ef}$ & NS & NS & NS \\
\hline & Pupa & $5.0 \pm 0.11 \mathrm{f}$ & $5.1 \pm 0.09 \mathrm{f}$ & $5.3 \pm 0.09 \mathrm{e}$ & $5.4 \pm 0.11 \mathrm{f}$ & NS & $<0.05$ & NS \\
\hline & Total & $10.3 \pm 0.14 \mathrm{f}$ & $10.7 \pm 0.15 f$ & $10.5 \pm 0.09 \mathrm{f}$ & $11.1 \pm 0.15 \mathrm{f}$ & $<0.05$ & NS & NS \\
\hline & $\mathrm{N}$ & 24 & 25 & 68 & 77 & & & \\
\hline \multirow{4}{*}{$30^{\circ} \mathrm{C}$} & Egg + larva & $4.9 \pm 0.23 \mathrm{e}$ & $4.9 \pm 0.07 \mathrm{~g}$ & $4.6 \pm 0.09 \mathrm{~g}$ & $4.9 \pm 0.14 f$ & NS & NS & NS \\
\hline & Pupa & $4.0 \pm 0.17 \mathrm{~g}$ & $4.3 \pm 0.06 \mathrm{~g}$ & $4.4 \pm 0.08 \mathrm{f}$ & $4.5 \pm 0.09 \mathrm{~g}$ & $<0.05$ & $<0.05$ & NS \\
\hline & Total & $8.9 \pm 0.9 \mathrm{f}$ & $9.2 \pm 0.06 \mathrm{~g}$ & $8.9 \pm 0.09 \mathrm{~g}$ & $9.5 \pm 0.1 \mathrm{~g}$ & $<0.001$ & NS & NS \\
\hline & $\mathrm{N}$ & 17 & 94 & 54 & 40 & & & \\
\hline
\end{tabular}

Values given are mean $\pm \mathrm{SE}$. Means with the same letters within the same stage and column are not significantly different by Tukey's HSD test after one-way ANOVA, $P<0.05$. NS $=$ not significant.

sis, respectively. In comparison, at $20^{\circ} \mathrm{C}$ developmental time dropped to about half on both species (20-21 days). Parasitoid development was completed after about 12 days at $25^{\circ} \mathrm{C}$ and 9 days at $30^{\circ} \mathrm{C}$. At all tested temperatures and on both hosts, the parasitoid pupal stage was slightly shorter than the egg-larva period except at $15^{\circ} \mathrm{C}$ for males ( $t$ test; $t=4.0, \mathrm{n}=48, P<0.001$ ) and females $(t$ $=1.97, \mathrm{n}=52, P<0.05)$ on $L$. chinensis, and for females $(t=2.19, \mathrm{n}=122, P<0.05)$ on $L$. trifolii, and at $17.5^{\circ} \mathrm{C}$ for females on $L$. chinensis ( $t=3.26, \mathrm{n}=92, P<0.001$ ), where the parasitoid showed a longer egg-larva period.

Development rate of $N$. okazakii from oviposition to completion of egg-larva, pupal and total immature stages increased with temperature over the range tested. Significant linear relationships were indicated for the regressions of mean development rate on temperature for each lifecycle stage (Table 2). From these equations, lower developmental thresholds (LDT) were estimated, which ranged from $10.7^{\circ}$ to $12.2^{\circ} \mathrm{C}$ for the egg-larva, pupal and total immature stages. Thermal constants (DD) of 166.7, 172.4 and 178.6 degree-days were estimated as the effective temperature sums for completing development of males on both hosts and of females on L. chinensis and L. trifolii, respectively.

\section{DISCUSSION}

Some species of the genus Neochrysocharis have bean reared on leafminers in the laboratory (Maryana, 2000; Tran et al., 2004; Hondo et al., 2006). However, few data on the development of $N$. okazakii on Liriomyza are available (Tran and Takagi, 2006). Our 
Table 1. Linear regression equations of development rate versus temperature, and estimated lower developmental threshold (LDT) and thermal constant (DD) for the immature stages of $N$. okazakii reared on L. chinensis and L. trifolii at different constant temperatures

\begin{tabular}{|c|c|c|c|c|c|c|c|c|c|}
\hline \multirow{2}{*}{ Sex } & \multirow{2}{*}{ Stage } & \multirow{2}{*}{ Slope $\pm \mathrm{SE}$} & \multirow{2}{*}{ Intercept $\pm \mathrm{SE}$} & \multicolumn{3}{|c|}{ ANOVA parameters } & \multirow{2}{*}{$R^{2}$} & \multirow{2}{*}{ LDT } & \multirow{2}{*}{$\mathrm{DD}$} \\
\hline & & & & $F$ & $\mathrm{df}$ & $P$ & & & \\
\hline \multicolumn{10}{|c|}{ L. chinensis } \\
\hline \multirow[t]{3}{*}{ Male } & Egg + larva & $0.0109 \pm 0.0005$ & $-0.1164 \pm 0.0113$ & 499.3 & 1,5 & $<0.0001$ & 0.990 & 10.7 & 91.7 \\
\hline & Pupa & $0.0135 \pm 0.0006$ & $-0.1652 \pm 0.0145$ & 458.8 & 1,5 & $<0.0001$ & 0.989 & 12.2 & 74.1 \\
\hline & Egg to adult & $0.0060 \pm 0.0002$ & $-0.0689 \pm 0.0035$ & 1549.5 & 1,5 & $<0.0001$ & 0.997 & 11.5 & 166.7 \\
\hline \multirow[t]{3}{*}{ Female } & Egg + larva & $0.0106 \pm 0.0003$ & $-0.1135 \pm 0.0059$ & 1758.9 & 1,5 & $<0.0001$ & 0.997 & 10.7 & 94.3 \\
\hline & Pupa & $0.0127 \pm 0.0004$ & $-0.1507 \pm 0.0089$ & 1075.0 & 1,5 & $<0.0001$ & 0.995 & 11.9 & 78.7 \\
\hline & Egg to adult & $0.0058 \pm 0.0001$ & $-0.0655 \pm 0.0034$ & 1591.3 & 1,5 & $<0.0001$ & 0.997 & 11.3 & 172.4 \\
\hline \multicolumn{10}{|c|}{ L. trifolii } \\
\hline \multirow[t]{3}{*}{ Male } & Egg + larva & $0.0114 \pm 0.0005$ & $-0.1291 \pm 0.0105$ & 624.5 & 1,5 & $<0.0001$ & 0.992 & 11.3 & 87.7 \\
\hline & Pupa & $0.0122 \pm 0.0007$ & $-0.1393 \pm 0.0164$ & 294.3 & 1,5 & $<0.0001$ & 0.983 & 11.4 & 81.9 \\
\hline & Egg to adult & $0.0060 \pm 0.0003$ & $-0.0694 \pm 0.0061$ & 510.5 & 1,5 & $<0.0001$ & 0.990 & 11.6 & 166.7 \\
\hline \multirow[t]{3}{*}{ Female } & Egg + larva & $0.0108 \pm 0.0006$ & $-0.1206 \pm 0.0129$ & 367.9 & 1,5 & $<0.0001$ & 0.987 & 11.2 & 92.6 \\
\hline & Pupa & $0.0119 \pm 0.0005$ & $-0.1356 \pm 0.0114$ & 579.8 & 1,5 & $<0.0001$ & 0.991 & 11.4 & 84.0 \\
\hline & Egg to adult & $0.0056 \pm 0.0003$ & $-0.0631 \pm 0.0058$ & 490.5 & 1,5 & $<0.0001$ & 0.989 & 11.3 & 178.6 \\
\hline
\end{tabular}

results indicated that $N$. okazakii could complete its development on both $L$. chinensis and $L$. trifolii at the tested temperature range of $15-30^{\circ} \mathrm{C}$. At an intermediate range of $25-30^{\circ} \mathrm{C}$, total development time was similar on the two host species. The result has demonstrated that the host species are almost equal in quality for $N$. okazakii development, at least, in terms of developmental time. Also, the result has shown that the development time of immature stages of $N$. okazakii on both host species is shorter than that of $N$. formosa on $L$. trifolii (i.e., $52.5,14$ and 11.9 days at $15^{\circ}, 25^{\circ}$ and $30^{\circ} \mathrm{C}$, respectively) (Hondo et al., 2006). Short developmental time is a crucial to biological control because developmental time can determine how quick a biocontrol agent can follow an increase of pest populations.

At all tested temperatures and on both hosts, male parasitoids developed faster than females did. This result is in agreement with Maryana (2000) for $N$. formosa on $L$. trifolii, and other eulophid parasitoids reared on $L$. trifolii (Minkenberg, 1990; Bazzocchi et al., 2003; Hondo et al., 2006).

No substantial deviations from linearity in the various stages and total development rate were observed with $N$. okazakii males and females reared on L. chinensis and $L$. trifolii over the temperature range tested. This result is consistent with previous studies, indicating that, at an intermediate range of temperatures (e.g., $15-30^{\circ} \mathrm{C}$ ), the developmental rate of most eulophid parasitoids of leafminers is linearly related to ambient temperatures (Minkenberg, 1990; Saito et al., 1997; Maryana, 2000; Bazoocchi et al., 2003; Hondo et al., 2006).

Estimated lower threshold temperatures of $N$. okazakii were similar regardless of the developmental stage, the sex and host species (range 10.7-12.2 ${ }^{\circ} \mathrm{C}$ ). Similar values are reported by Maryana (2000) and
Hondo et al. (2006) for N. formosa (10.6 and $10.4^{\circ} \mathrm{C}$ for male and female, respectively) and Hemiptarsenus varicornis $\left(11.8^{\circ} \mathrm{C}\right)$ reared on L. trifolii. Hondo et al. (2006) also report lower values for five other eulophid parasitoids reared on L. trifolii (Pnigalio katonis, Diglyphus isaea, D. minoeus, D. pusztensis and Chrysocharis pentheus).

Bazzocchi et al. (2003) report a significant difference between estimated DD values for $D$. isaea between host species, i.e., L. trifolii and L. huidobrensis. However, our findings showed that male $N$. okazakii reared on both $L$. trifolii and L. chinensis required a similar DD to complete the development, while DD values for females reared on $L$. trifolii were slightly higher than those on L. chinensis. The result again suggests both host Liriomyza is almost equal in host quality for $N$. okazakii. Given the wide range of linearity in the developmental rate curves, the DD concept may be useful in predicting number of generations of the eulophid parasitoids in the field (Pereira et al., 2011).

Several factors affect the cost-competitiveness of biological control agents as an option for pest control. For many natural systems, the agents are mass-produced using the natural host or prey, which itself has been reared on one of its normal food plants. Therefore, those systems usually require intensive labor to rear plants and hosts (or prey organisms), which will make the production cost of biocontrol agents expensive, and consequently the use of natural enemies is a unfavored option. The production costs can normally be lowered only by reducing the costs of raw materials, largely by finding cheaper substitutes at either the plant or herbivore trophic level in a rearing system (van Driesche and Bellows, 1996). The host plants of L. chinensis are Allium spp. (Spencer, 1973), and ideally Welsh onion 
should be used as normal host food in a natural rearing system for $N$. okazakii to ensure that the parasitoids are well adapted to L. chinensis. Because onion plants are slow-growing, their use in a mass-rearing system is not conducive to producing large numbers of parasitoids at an economical price. In addition, to keep parasitoid survival high, removal of parasitized leafminers from onion leaves is required when onion-L. chinensis system is used to rear the parasitoid because onion leaves deteriorate during the final rearing process of parasitoids developing on L. chinensis (i.e., parasitoid emergence stage). Our findings have shown that L. trifolii is suitable for development of $N$. okazakii as with L. chinensis. Thus, L. trifolii and kidney bean could be used to improve the mass-rearing system of $N$. okazakii because mass-rearing of L. trifolii with kidney bean is easier and more cost-effective.

\section{ACKNOWLEDMENTS}

We thank Ms T.T.D. Hanh and Ms L.T. Thiet for their assistance on insect collection and rearing. This work was supported in part by a Grand-in-Aid from the Vietnam National Foundation for Science and Technology Development (NAFOSTED) (No. 106.16.60.09).

\section{REFERENCES}

Arakaki, N. and K. Kinjo 1998 Notes on the parasitoid fauna of the serpentine leafminer Liriomyza trifolii (Burgess) (Diptera: Agromyzidae) in Okinawa, Southern Japan. Appl. Entomol. Zool., 33: 577-581

Bazzocchi, G., G. A. Lanzoni, G. Burgio and M. R. Fiacconi 2003 Effects of temperature and host on the pre-imaginal development of the parasitoid Diglyphus isaea (Hymenoptera: Eulophidae). Biol. Control, 26: 74-82

Bjorksten T. A., M. Robinson and J. La Salle 2005 Species composition and population dynamic of leafmining flies and their parasitoid in Victoria. Aust. J. Entomol., 44: 186-191

Campbell A., B. D. Frazer, N. Gilbert, A. P. Gutierrez and A. P. Mackauer 1974 Temperature requirements of some aphids and their parasites. J. Appl. Ecol., 11: 431-438

Hondo T., A. Koike and T. Sugimoto 2006 Comparison of thermal tolerance of seven native species of parasitoids (Hymenoptera: Eulophidae) as biological control agents against Liriomyza trifolii (Diptera: Agromyzidae). Appl. Entomol. Zool., 41: 73-82

Jarošík V., A. Honěk and A. F. G. Dixon 2002 Developmental rate isomorphy in insects and mites. Am. Nat., 160: 497-510

Konishi K. 2004 An illustrated to the species of hymenopterous parasitoids of leafmining agromyzid pests. In "Proceedings of 2004 Asian science seminar on biological control of agricultural pests in Asia - Theory and Practice". JASS' 04, Fukuoka,
Japan, pp: 40-56

Lactin D. J., N. J. Holliday D. L. Johnson and R. Craigen 1995 Improved rate model of temperature-dependent development by arthropods. Environ. Entomol., 24: 68-75

Maryana N. 2000 Studies on the ecological aspects of Neochrysocharis formosa (Hymenoptera: Eulophidae) attacking Liriomyza trifolii (Diptera: Agromyzidae). PhD thesis, Kyushu University

Minkenberg, O. P. J. M. 1990 On seasonal inoculative biological control. Wageningen Agricultural University, The Netherlands, $\mathrm{PhD}$ thesis

Minkenberg O. P. J. M. and C. A. J. Helderman 1990 Effect of temperature on the life history of Liriomyza bryoniae (Diptera: Agromyzidae) on tomato. J. Econ. Entomol., 83 117-125

Murphy S. T. and J. LaSalle 1999 Balancing biological control strategies in the IPM of New World invasive Liriomyza leafminers in field vegetable crops. Biocontrol News and Information, 20: 91-104

Pereira F. F., J. C. Zanuncio, H. N. Oliveira, E. L. V. Grance, P. L. Pastori and M. D. Gava-Oliveira 2011 Thermal requirements and estimate number of generations of Palmistichus elaeisis (Hymenoptera: Eulophidae) in different Eucalyptus plantations regions. Brazilian J. Biol. 71: 431-436

Saito T., A. Ozawa and F. Ikeda 1997 Developmental time of ectopharasitoid, Hemiptarsenus varicornis, on Liriomyza trifolii and L. bryoniae. Jpn. J. Appl. Entomol. Zool., 41 161-163 (in Japanese with English summary)

Spencer, K. A. 1973 Agromyzidae (Diptera) of Economic Importance. Dr. W. Junk B. V., Publishers, The Hague

SAS Institute Inc. 1998 StatView 5.O.J. SAS Institute Inc., Cary, $\mathrm{NC}$

Tran D. H., M. Takagi and K. Takasu 2004 Effects of selective insecticides on host searching and oviposition behavior of Neochrysocharis formosa (Westwood) (Hymenoptera: Eulophidae), a parasitoid of the American serpentine leafminer. Appl. Entomol. Zool., 39: 435-441

Tran, D. H. and M. Takagi 2005 Developmental biology of the stone leek leafminer Liriomyza chinensis (Diptera: Agromyzidae) on onion. J. Fac. Agr., Kyushu Univ. 50: 375-382

Tran D. H. and M. Takagi 2006 Biology of Neochrysocharis okazakii Kamijo (Hymenoptera: Eulophidae), a parasitoid of the stone leek leafminer Liriomyza chinensis (Diptera: Agromyzidae). J. Fac. Agr., Kyushu Univ., 51: 269-273

Tran D. H., T. T. A. Tran, K. Konishi and M. Takagi 2006 Abundance of the parasitoid complex associated with Liriomyza spp. (Diptera: Agromyzidae) on vegetable crops in central and southern Vietnam. J. Fac. Agr., Kyushu Univ., 51: $115-120$

Tran D. H., T. Ueno T. and M. Makagi 2007 Comparison of the suitability of Liriomyza chinensis and L. trifolii (Diptera: Agromyzidae) as hosts for Neochrysocharis okazakii (Hymenoptera: Eulophidae). Biol. Cont., 41: 354-360

Van Driesche R. G. and T. S. Bellows 1996 Biological Control. New York, Chapman and Hall

Waterhouse D. F. and K. R. Norris 1987 Liriomyza species (Diptera: Agromyzidae) leafminers. In "Biological Control: Pacific Prospects" ed. By D. F. Waterhouse and K. R. Norris. Inkata Press, Melbourne, Australia, pp. 159-176 